\title{
1.5. Edukacja włączająca w badaniach naukowych - perspektywa rodzica
}

DOI: $10.47050 / 65591838.92-105$

Iwona Chrzanowska

Skuteczna edukacja włączająca wymaga zaangażowania rodziców uczniów. Ważne są ich postawy wobec tej idei, a znaczenie ma również ich zaangażowanie w proces edukacji dziecka i współpraca z nauczycielami. Z badań wynika, że większość z nich deklaruje akceptację dla wspólnego kształcenia. Niektórzy rodzice dzieci z niepełnosprawnością wykazują jednak sceptycyzm, zwłaszcza w odniesieniu do kwalifikacji kadry, wyposażenia szkół i wsparcia uczniów. Obawiają się nieprawidłowych relacji z rówieśnikami (izolacji, wykluczenia). Problemem jest także zbyt późna diagnoza zaburzeń rozwojowych.

\section{Słowa kluczowe:}

rodzice w edukacji włączającej

oczekiwania 


\subsection{Inclusive education in scientific research - parent's perspective}

DOI: 10.47050/65591838.92-105

Iwona Chrzanowska

Effective inclusive education requires the support of pupils' parents. In this case, parents' attitudes towards inclusive education are important, as are parents' involvement in the child's education process and cooperation with teachers. The research shows that the majority of them declare acceptance of the idea of joint education. Some parents of children with disabilities, however, show some skepticism, especially regarding the qualifications of the staff, system of support, peer relations. The problem is also too late diagnosis of developmental disorders.

\section{Keywords:}

\section{parents in inclusive education}

\section{expectations}




\section{Rodzice wobec edukacji włączającej}

Odnosząc się do tytułowego zagadnienia warto skupić się na kilku wątkach: nastawienia, postaw rodziców wobec idei edukacji włączającej i ich uwarunkowań, zaangażowania rodziców w proces edukacji dzieci, w tym współpracy z przedszkolem i szkołą.

Odwołując się do strukturalnego modelu postaw Lewisa R. Aikena (2002) istotne jest rozpoznanie uwarunkowań powstawania odpowiednich nastawień, z uwzględnieniem trzech komponentów postawy: poznawczego, afektywnego i behawioralnego. Komponent poznawczy to wiedza i przekonania dotyczące przedmiotu postawy. Komponent afektywny odnosi się do uczuć, emocji, a składnik behawioralny koncentruje się na doświadczeniu - to intencjonalne bądź realne zachowania człowieka wobec przedmiotu postawy (np. Eagly, Chaiken 1993; Wojciszke 2000). Szukając warunków kształtowania się postaw, badacze wskazują na zasoby indywidualne i społeczne (Mądrzycki 1997). W kwestii rozpoznawania uwarunkowań kształtowania się postaw osób dorosłych, w tym wypadku rodziców, warto odnieść się zwłaszcza do czynników indywidualnych. Pozwoli to zrozumieć zróżnicowanie postaw, a jednocześnie stosować bardziej świadome i trafne działania, zmierzające do stopniowej zmiany negatywnych nastawień niesprzyjających integracji społecznej.

Jedną z istotnych koncepcji, którą można tutaj przywołać, jest salutogeneza Arrona Antonovsky'ego (1995). Centralnym pojęciem jest w niej "poczucie koherencji” - rozumiane jako zgeneralizowany emocjonalno-poznawczy sposób pojmowania świata, który pozwala na dostrzeganie i odbiór otaczających zjawisk jako zrozumiałych, poddających się kontroli i mających sens, a zatem wartych podejmowania wysiłku oraz inwestowania emocjonalnego. Poczucie koherencji na wysokim poziomie sprzyja radzeniu sobie z realizowaniem zadań życiowych, zaspokajaniu potrzeb i stosowaniu mechanizmów przezwyciężania trudności (m.in. Czabała, Sęk 2000; Pasikowski 2000). Definiowane są trzy wymiary poczucia koherencji, do których zaliczane są: zrozumiałość, zaradność lub sterowalność i sensowność. Poczucie zrozumiałości dotyczy poznawczego aspektu sytuacji. Informacje mogą być postrzegane jako spójne, uporządkowane, ustrukturowane i jasne lub chaotyczne, nieuporządkowane, losowe, przypadkowe bądź niewytłumaczalne (Antonovsky 1995, s. 32). Osoba z silnym poczuciem zrozumiałości będzie w stanie dokonać poznawczej oceny informacji 
(bodźców), nawet jeśli będą one niechciane, niepożądane, zagrażające czy niespodziewane. Będzie w stanie je wyjaśnić (Antonovsky 1997). Osoba zaradna ma poczucie, że poradzi sobie z każdym, nawet niepomyślnym zdarzeniem. W trudnej sytuacji może aktywnie wpływać na sytuację. Umie sama poradzić sobie z trudnością lub wie, do kogo zwrócić się o skuteczną pomoc. Przyjmuje postawę aktywną i próbuje rozwiązać problemy (Antonovsky 1995). Poziom sensowności to wymiar emocjonalno-motywacyjny, wyrażający się zaangażowaniem we własne życie, wiarą w sens działań, wysiłkiem, poświęceniem i zaangażowaniem (Antonovsky 1997). Nie oznacza to, że osoby o wysokim poczuciu koherencji postrzegają cały świat jako zrozumiały, sterowalny i sensowny. Zazwyczaj dotyczy to obszarów istotnych dla ich funkcjonowania.

Już badania Antonovsky'ego (1995) wskazywały, że silne poczucie koherencji cechuje ludzi otwartych na innych i na ich potencjalne problemy. W miarę spadku poczucia koherencji obserwuje się coraz większą tendencję odgradzania się od innych i zamykania w sobie. Z analiz Janusza Kirenki (2015, s. 110) wynika z kolei, że osoby o postawie tolerancyjnej uzyskują w badaniach wyższe wyniki w zakresie poczucia koherencji niż osoby dystansujące się. Dotyczy to wszystkich komponentów.

Wyniki prac naukowców nad problematyką nastawienia i postaw wobec edukacji włączającej można przedstawić w dwóch odsłonach - w odniesieniu do rodziców uczniów sprawnych i rodziców uczniów ze specjalnymi potrzebami edukacyjnymi, w tym z niepełnosprawnością.

W Polsce nie ma wielu badań dotyczących opinii rodziców na temat edukacji włączającej, ten temat jest bardziej popularny poza naszymi granicami. Ogólny wniosek z prowadzonych analiz jest taki, że większość rodziców uczniów z niepełnosprawnością i bez niej deklaruje akceptację dla idei wspólnego kształcenia (Grzelak i in. 2014; Marciniak-Paprocka 2017; Hilbert 2014).

Niektórzy rodzice dzieci z niepełnosprawnością lub ze specjalnymi potrzebami edukacyjnymi wykazują jednak pewien sceptycyzm, zwłaszcza w odniesieniu do kwalifikacji kadry i wyposażenia szkół (Bennett, Gallagher 2013). Mówią także o niebezpieczeństwie społecznej izolacji uczniów z niepełnosprawnością w zwykłej klasie szkoły ogólnodostępnej (Leyser, Kirk 2004). Obawy tego rodzaju dostrzec można zwłaszcza w opiniach rodziców dzieci ze znacznym stopniem niepełnosprawności. Nie wyrażają oni poparcia dla idei włączania (Palmer, Fuller, Arora, Nelson 2001), choć i to nie jest normą. Jak poka- 
zują wyniki badań (Gallagher, Floyd, Stafford, Taber i in. 2000), rodzice mogą być zadowoleni z efektów edukacyjnych i korzyści społecznych ze wspólnej nauki, zwłaszcza gdy dziecko uczestniczy w zintegrowanych programach kształcenia od przedszkola po szkołę średnią.

Rodzice dzieci z niepełnosprawnością są pozytywnie nastawieni do przedszkolnej edukacji włączającej. W badaniach Iwony Myśliwczyk (2016) respondenci zwracali uwagę na takie kwestie jak: przebywanie z pełnosprawnymi rówieśnikami jako przygotowanie do funkcjonowania w otwartym środowisku, rozwój kompetencji i możliwość ich nabywania w relacjach z rówieśnikami. Nie do końca interesują ich formalne kwalifikacje nauczycieli, bardziej pozytywne rezultaty ich pracy widoczne w kompetencjach dzieci. Nie wszyscy rodzice są zadowoleni z efektów wspólnego kształcenia czy metod pracy (Twardowski 2009, s. 24).

Wśród głównych powodów wyboru włączających form edukacji w szkołach ogólnodostępnych na poziomie podstawowym wymieniane są: bliskość miejsca zamieszkania, możliwość rozwoju wśród pełnosprawnych rówieśników, najlepsze dopasowanie szkoły do potrzeb dziecka. W wypadku szkół integracyjnych wskazuje się: najlepsze dopasowanie placówki do potrzeb dziecka i możliwość rozwoju wśród pełnosprawnych rówieśników (Grzelak i in. 2014, s. 63). Na poziomie gimnazjum w szkołach ogólnodostępnych są to: możliwość rozwoju wśród pełnosprawnych rówieśników, najlepsze dopasowanie placówki do potrzeb dziecka, bliskość miejsca zamieszkania. W szkołach integracyjnych: rozwój wśród pełnosprawnych rówieśników, najlepsze dopasowanie szkoły do potrzeb dziecka (Grzelak i in. 2014, s. 68). Wybór placówki ogólnodostępnej na etapie ponadgimnazjalnym rodzice motywują: przeświadczeniem o tym, że dziecko nauczy się tam zawodu, rozwinie wśród pełnosprawnych rówieśników, a sama szkoła będzie dostosowana do jego potrzeb i zainteresowań. W przypadku szkół integracyjnych czynnikami motywacyjnymi są: dostosowanie do potrzeb ucznia, przeświadczenie o skuteczności nauki zawodu, szansa na zdobycie pracy (Grzelak i in. 2014, s. 72). We wszystkich tych kategoriach analiz powtarzającym się motywem jest dążenie rodziców do tego, by ich dzieci rozwijały się wśród pełnosprawnych rówieśników. Nie ma zatem wątpliwości, że jest to najsilniejszy motyw, a zarazem najważniejsza kwestia w wyborze ścieżki kształcenia - tym samym uznać można, że rodzice uczniów z zaburzeniami rozwoju i z niepełnosprawnością są zdecydowanymi zwolennikami edukacji włączającej. 
Większość rodziców dzieci bez niepełnosprawności również wspiera koncepcję wspólnego kształcenia: $64 \%$ badanych ujawnia ogólnie pozytywne postawy wobec inkluzji, $26 \%$ neutralne, a $10 \%$ negatywne. Niemniej pojawiają się obawy o to, czy wspólne kształcenie nie spowoduje większej koncentracji nauczyciela na uczniu ze specjalnymi potrzebami, czy nie pojawią się problemy związane z zachowaniem dzieci z niepełnosprawnością. Zdaniem 78\% rodziców uczniów bez niepełnosprawności, wspólne kształcenie nie przyczyni się do wzrostu kompetencji szkolnych ich dzieci, a $22 \%$ sądzi, że przełoży się na spadek indywidualnego kontaktu ich dzieci z nauczycielem. Przeważająca część rodziców pozytywnie ocenia z kolei wpływ praktyk włączających na rozwój emocjonalny: 67\% wskazuje na wzrost akceptacji różnic między ludźmi, dotyczących zachowania i wyglądu, 29\% na zwiększenie samooceny (Peck, Staub, Gallucci, Schwartz 2004). Z badań realizowanych w Polsce wynika, że wśród korzyści z edukacji włączającej rodzice wymieniają również: uczenie się tolerancji i akceptacji $(93,5 \%)$, kształtowanie empatii $(81,7 \%)$, otwieranie się na świat i docenianie różnorodności $(77,4 \%)$, korzyści dla obu grup (71\%), motywację do lepszej pracy dla nauczyciela (37,6\%). Wśród zagrożeń wymienia się to, że we wspólnym środowisku dzieci z niepełnosprawnością mogą się czuć gorsze $(59,1 \%)$, a także to, że to na nich, a nie na całej klasie, skoncentrowana będzie uwaga (30,1\%) (Marciniak-Paprocka 2017, s. 151).

Ciekawie przedstawiają się na tym tle wyniki badań Zdzisława Kazanowskiego (2011, s. 261) dotyczące reakcji emocjonalnych związanych ze wspólnym kształceniem osób sprawnych i z niepełnosprawnością intelektualną. W pierwszej grupie obserwuje się więcej negatywnych ustosunkowań emocjonalnych. Jednocześnie występują silniejsze pozytywne reakcje związane z segregacyjnym kształceniem. Omawiane badania dotyczyły wpływu zmian pokoleniowych na postawy wobec osób z niepełnosprawnością intelektualną. Respondentami byli rodzice i ich dorastające dzieci (średnia wieku 17,77 roku). Istotne jest, że osoby młode były większymi niż ich rodzice zwolennikami segregacyjnego kształcenia uczniów z niepełnosprawnością intelektualną, co-zdaniem autora badań - jest zagrożeniem dla rozwoju włączającego modelu kształcenia (Kazanowski 2011, s. 261). 


\section{Satysfakcja - jakie uwarunkowania?}

Perspektywa rodzica osoby z niepełnosprawnością lub ze specjalnymi potrzebami edukacyjnymi. Wybór ścieżki kształcenia to jeden z najtrudniejszych momentów w byciu rodzicem dziecka z niepełnosprawnością (Szwed 2012, s. 71). Decyzja w sprawie określonego rodzaju szkoły (specjalnej, integracyjnej, ogólnodostępnej) oznacza nie tylko inną wizję edukacji i jej efektów, ale - jak wskazuje Sylwia Szwed - również inną wizję niepełnosprawności. Przedstawiając perspektywę rodzicielskich refleksji związanych z dokonanym w przeszłości wyborem, ukazuje jednoczesnie charakterystyczne dylematy naukowców i badaczy zagadnienia. Wynikają one z tego, jakie możliwości stworzyła każdego rodzaju szkoła oraz jakie były perspektywy sprostania przez dziecko stawianym wymaganiom. Dla niektórych rodziców szkoła, np. integracyjna, stała się rozwiązaniem otwierającym, podstawą nabycia kompetencji społecznych umożliwiających dziecku samodzielne i niezależne funkcjonowanie. Inni sądzą, że jest to strata czasu. Ich zdaniem szkoda wysiłku na nabywanie nieprzydatnych, zatem i nietrwałych kompetencji związanych np. z przedmiotami nauczania w szkole, przy jednoczesnym braku kształcenia umiejętności podstawowych, umożliwiających samodzielne funkcjonowanie (np. przemieszczania się, realizacji najprostszych potrzeb) bez udziału osób trzecich. Niektórzy rodzice dzieci z niepełnosprawnością są bardzo negatywnie nastawieni do segregacyjnych form kształcenia, padają mocne określenia, porównujące szkołę specjalną z gettem (Szwed 2012). Dla innych jednak jest to miejsce, w którym ich dziecko nabywa umiejętności, ale i cechy osobowe, pozwalające mu planować szczęśliwe życie. Uczniowie niewidomi umiejący się samodzielnie przemieszczać (także poza terenem szkoły) czy osoby niesłyszące, które potrafią czytać z ruchu warg, mają większe szanse na kontynuowanie kształcenia w systemie niesegregacyjnym (i nierzadko z tych szans korzystają). Wydaje się, że współpraca z pedagogiem specjalnym, zwłaszcza w przypadku poważnych zaburzeń rozwoju, jest koniecznym warunkiem osiągnięcia przez taką osobę sukcesu edukacyjnego i życiowego.

Uwarunkowanie I-swoboda wyboru placówki kształcenia. Jakwykazują analizy, zdecydowana większość rodziców dzieci z niepełnosprawnością, wybiera dla nich placówki ogólnodostępne i integracyjne. Na poziomie przedszkola to odpowiednio $79,1 \%$ i 17,2\% (placówki publiczne) oraz 
65,4\% i 25,9\% (niepubliczne) (Grzelak, Kubicki, Orłowska 2014, s. 41). W przypadku szkoły podstawowej pierwszym wyborem jest najczęściej placówka ogólnodostępna (72,3\%), następnie integracyjna $(16,7 \%)$ i specjalna (11\%) (Grzelak i in. 2014, s. 47-48).

Około $48 \%$ rodziców dzieci z niepełnosprawnością na poziomie szkoły podstawowej deklaruje, że ma możliwość swobodnego wyboru placówki kształcenia dla dziecka. Najmniej optymistycznie przedstawia się to w małych miastach (do 20 tys. mieszkańców), gdzie przywilej ten ma 36,9\% uczestników badania. Niewiele lepiej jest na terenach wiejskich - 40,9\%. Najkorzystniejsza jest sytuacja w dużych miastach (powyżej 500 tys. mieszkańców), gdzie ponad 65\% rodziców ma swobodę wyboru.

Na etapie gimnazjum możliwość wyboru ma już jedynie $45 \%$ badanych. Najmniej korzystna jest sytuacja rodziców i uczniów z terenów wiejskich oraz z małych miejscowości (odpowiednio: 38,9\% i 41,7\%), najlepsza - w dużych miastach $(61,7 \%)$.

Głównym powodem wyboru placówek ogólnodostępnych i integracyjnych - w opinii rodziców - jest chęć, by dziecko rozwijało się wśród sprawnych rówieśników. Z kolei w przypadku szkoły specjalnej i integracyjnej chodzi o to, by uczyło się wśród innych dzieci z niepełnosprawnością. Okazuje się również, że jeśli wziąć pod uwagę zainteresowania dziecka, na pierwszym miejscu znajduje się szkoła ogólnodostępna, na ostatnim zaś - specjalna (Grzelak i in. 2014, s. 56-57).

\section{Uwarunkowanie II - zbyt późna diagnoza zaburzeń rozwojowych.}

Wyniki analiz wskazują, że u ponad $71 \%$ dzieci z lekką niepełnosprawnością intelektualną rozpoznanie problemów rozwojowych następuje po szóstym, a u $26 \%$ - po dziesiątym roku życia. W przypadku niepełnosprawności intelektualnej umiarkowanej i znacznej, które są łatwiejsze do zdiagnozowania, rozpoznanie u $24 \%$ dzieci następuje dopiero po szóstym, a u 5\% - po dziesiątym roku życia. Z kolei $49 \%$ dzieci z zaburzeniami ze spektrum autyzmu (ASD) uzyskuje diagnozę przed szóstym, a 17\% dopiero po dziesiątym roku życia (Grzelak, Kubicki, Orłowska 2014, s. 32-34). Późniejsze wykrycie niepełnosprawności oznacza opóźnienie specjalistycznego wsparcia, często także wczesnego wspomagania rozwoju, kluczowego dla dalszego funkcjonowania. W wielu sytuacjach wiąże się to również z trudnością wyboru właściwej ścieżki kształcenia. Warto przy tym sobie uzmysłowić, że kwestie zbyt 
późnej diagnozy zaburzeń rozwojowych to zagadnienie, które od wielu lat jest podejmowane w badaniach naukowych. Jan Pańczyk już w latach 90. XX w. wskazywał tę kwestię w związku z diagnozą niepełnosprawności (Pańczyk 1990; Głodkowska 1999).

\section{Uwarunkowanie III - relacje między możliwościami przedszkoli i szkół} a potrzebami dzieci. $Z$ badań wynika, że na poziomie przedszkola do innych placówek, decyzją rodziców, przenoszonych jest $13 \%$ dzieci z niepełnosprawnościami, na poziomie szkoły podstawowej-aż 30,5\%. W przypadku przedszkoli najważniejszym z powodów przenoszenia dzieci jest brak możliwości zaspokojenia przez placówkę potrzeb osób z niepełnosprawnością - wskazuje na niego $20 \%$ rodziców (Grzelak i in. 2015 , s. 40-42). W przypadku szkół podstawowych najczęstszą przyczyną zmiany jest to, że dziecko nie radziło sobie z wymaganiami szkoły z uwagi na niepełnosprawność, przy czym częściej na ten problem zwracają uwagę rodzice dzieci zabieranych z placówek integracyjnych, a rzadziej z ogólnodostępnych. W przypadku uczniów, dla których wybór szkoły okazał się nieudany, placówką pierwszego wyboru była zwykle szkoła ogólnodostępna (ok. 60\%), rzadziej integracyjna (ponad 30\%) i specjalna (8,8\%). Głównym powodem rezygnacji ze szkoły pierwszego wyboru, wskazywanym przez rodziców, było niedostosowanie szkoły do potrzeb dziecka-29,4\% (Grzelak i in. 2014, s. 47-48).

Znacznie niższe są wskaźniki zmiany placówki kształcenia w wypadku gimnazjum (dotyczy to ok. 5,4\% uczniów). Zdecydowanie najczęściej dzieje się tak w wypadku ogólnodostępnej (69\%), znacznie rzadziej integracyjnej (16\%). Głównym powodem poszukiwania innej placówki jest, w opiniach rodziców, nieradzenie sobie w szkole z uwagi na niepełnosprawność (40\% szkoła ogólnodostępna, 26,7\% - integracyjna) (Grzelak i in. 2014, s. 65-66). Analizy Instytutu Badań Edukacyjnych potwierdzają prawidłowość, że im dłużej uczeń pozostaje w danej formie kształcenia, tym mniejsze ryzyko, że będzie ją zmieniał (Grzelaki in. 2014, s. 50). Wraz z przechodzeniem na kolejne etapy edukacyjne zmniejsza się liczba uczniów, którzy modyfikują pierwotny wybór placówki. Zauważyć jednak należy, że prawdopodobnie dzieje się tak nie dlatego, że oferowane są w nich lepsze warunki włączania w porównaniu ze szkołami na poziomach poprzedzających, ale w związku z tym, że pozostała w nich młodzież ujawnia potencjalnie najniższy poziom zaburzeń i zakłóceń rozwojowych, mogła sobie zatem poradzić w szkole. 
Inną przyczyną mógł być splot sprzyjających czynników, w tym silne wsparcie rodziny i szkoły.

Uwarunkowanie IV - efektywna współpraca. Warunkiem koniecznym powodzenia działań włączających jest współdziałanie rodziców z nauczycielem (Christenson, Sheridan 2001; Hendersen, Mapp 2002; Twardowski 2012). Dotyczy to zwłaszcza głównych celów kształcenia, zaangażowania i determinacji w działaniu (Carlisle, Stanley, Kemple 2005; Epstein 2001). Rodzice są pierwszymi opiekunami i nauczycielami dziecka. Łączą ich z nim silne relacje, zazwyczaj pozbawione lęku i niepewności, które pojawiają się w kontakcie z osobą spoza rodziny. W wielu wypadkach są także świetnymi specjalistami, rehabilitantami swoich dzieci (Twardowski 2002; McWilliam 2010). Jednym z głównych warunków dobrej współpracy między nauczycielami i rodzicami jest skuteczna komunikacja, a ta ma szanse zaistnieć jedynie wtedy, gdy nie będzie jednostronna (nadawca - nauczyciel, odbiorca - rodzic) (Taylor, Smiley, Richards 2009), skoncentruje się na wymianie informacji (Lee, Low 2013) i będzie oparta na chęci uczenia się od siebie i szacunku. Rodzic nie może być w tej relacji traktowany jako pomocnik nauczyciela/specjalisty czy wykonawca jego poleceń, ale jako równoprawny uczestnik procesu (Twardowski 2012, s. 10). Być może wówczas zmieni się stereotypowy obraz roszczeniowego rodzica ucznia z niepełnosprawnością (Anannikova 2015; Kubicki, Dudzińska, Olcoń-Kubicka 2012; Grzelak i in. 2014).

\section{Uwarunkowanie V - problemy w funkcjonowaniu szkolnym} dzieci/uczniów z niepełnosprawnością, specjalnymi potrzebami edukacyjnymi. Głównym powodem zmiany placówki kształcenia jest fakt, że dziecko nie radzi sobie z wymaganiami szkoły z uwagi na występujące zaburzenia, zakłócenia rozwoju. Na etapie szkoły podstawowej z tego powodu przeniesionych do innych rodzajów (typów) szkół zostało: 35,5\% uczniów placówek ogólnodostępnych, 44,2\% integracyjnych i $17,2 \%$ specjalnych, w gimnazjum to odpowiednio: $40 \%, 26,7 \%$ i $23,1 \%$. Wymagań programowych nie spełnia w szkole podstawowej analogicznie: 10,1\%, 3,5\% i 1,7\% uczniów, w gimnazjum 20\% w przypadku edukacji ogólnodostępnej (Grzelak i in. 2014, s. 48, 66). Część rodziców dzieci z niepełnosprawnością wskazuje również, że powodem zmiany placówki kształcenia były problemy w relacjach z rówieśni- 
kami. Doświadczyło ich $11 \%$ dzieci na etapie edukacji przedszkolnej ${ }^{1}$, $6,1 \%$ na etapie szkoły podstawowej ${ }^{2}$ ogólnodostępnej, 5,8\% - integracyjnej i 8,6\% - specjalnej, 7,3\% - w gimnazjum ogólnodostępnym ${ }^{3}$, $20 \%$ - w integracyjnym, 15,4\% - w specjalnym (Grzelak i in. 2014, s. 42,48$)$.

Wyniki przedstawionych tu analiz wskazują na kilka istotnych czynników warunkujących satysfakcję rodziców z wyboru placówki kształcenia. Można je również potraktować szerzej, jako predyktory edukacji włączającej czy nawet wyzwanie związane z kształceniem osób ze specjalnymi potrzebami edukacyjnymi w Polsce. Odnoszą się one pośrednio do kompetencji kadry pedagogicznej, a także warunków kształcenia, wsparcia ucznia oraz nauczyciela w pracy zawodowej. Można byłoby je sprowadzić do wymagania stosowania w ramach działań dydaktycznych projektowania uniwersalnego w zakresie metod lub form organizacyjnych. $Z$ kolei $w$ ramach działań wychowawczych - do umiejętności pracy w grupie zróżnicowanej, budowania dobrego klimatu szkoły, współpracy ze specjalistami i rodzicami, a w sytuacjach koniecznych - uruchamiania programów wychowawczych przeciwdziałających zachowaniom niewłaściwym w relacjach rówieśniczych.

\section{Perspektywa rodzica dziecka sprawnego}

Uwarunkowanie I - deklaratywność postaw i obawa o obniżenie poziomu kształcenia. Rodzice dzieci sprawnych obawiają się, że edukacja włączająca wpłynie na obniżenie poziomu kształcenia. Zakładają, że w sytuacji, gdy w szkole pojawi się uczeń z niepełnosprawnością, z zaburzeniami czy z zakłóceniami w rozwoju, nauczyciel dostosuje do niego proces edukacyjny. Nawet jeśli to nie nastąpi, uważają, że będzie zmuszony poświęcić mu więcej uwagi niż innym osobom w klasie, w tym sprawnym, którzy lepiej radzą sobie z wymaganiami szkoły, czyli potencjalnie nie potrzebują większego wsparcia. Opinie takie związane są poniekąd z oceną szkoły: jej zdolnością do realizacji zadań statutowych i jakością oferowanego kształcenia. $Z$ jednej stro-

\footnotetext{
n dla dzieci zmieniających przedszkole to 303 osoby.

n dla uczniów zmieniających szkołę podstawową to 523 osoby.

n dla uczniów zmieniających gimnazjum to 81 osób.
} 
ny wskaźniki badań międzynarodowych odnoszących się do poziomu nauczania w polskich szkołach wskazują na poprawę umiejętności podstawowych uczniów, np. tych dotyczących umiejętności czytania ze zrozumieniem, rozumowania i interpretacji tekstu. Badania OECD PISA pokazują, że w 2000 r. polscy piętnastolatkowie plasowali się poniżej średniej OECD, w 2003 r. osiągnęli średnią, a w 2006 r. znaleźli się powyżej (Federowicz, Sitek 2012, s. 2). Z drugiej strony obecnie coraz więcej uwagi zwraca się nie tyle na wartości wskaźników obiektywnych, ile na efekty w postaci wiadomości, umiejętności i kompetencji rozumianych jako zdolność do stosowania posiadanej wiedzy i umiejętności w różnych sytuacjach: osobistych, społecznych, zawodowych. Ważne jest również uaktualnianie wiedzy i umiejętności, nabywanie nowych kompetencji i kwalifikacji, czyli uczenie się dorosłych. W tym obszarze Polska osiąga jedne z najsłabszych wyników w Unii Europejskiej i OECD (Federowicz, Sitek 2012, s. 2).

Z badań Katarzyny Marciniak-Paprockiej ${ }^{4}$ wynika, że 79,5\% rodziców dzieci sprawnych deklaruje aprobujące nastawienie do edukacji włączającej (Marciniak-Paprocka 2017, s. 144), 63,4\% ma pozytywny, a 33,3\% raczej pozytywny stosunek do wspólnego kształcenia i wychowania ich dzieci wspólnie z niepełnosprawnymi rówieśnikami (tamże, s. 150). Dodać należy, że już jedynie 40,9\% jest zdania, iż pomoc psychologiczno-pedagogiczna jest udzielana wszystkim uczniom, a nie jedynie tym ze specjalnymi potrzebami, z niepełnosprawnością. Dodatkowo ok. $20 \%$ rodziców wyraża przekonanie, że nie trafia ona do wszystkich potrzebujących poza osobami z niepełnosprawnością (tamże, s. 151).

Uwarunkowanie II - aspiracje rodziców. Wyniki badań wskazują wysokie aspiracje rodziców wobec wykształcenia swoich dzieci. Ponad połowa $(52,5 \%)$ chce, by ich dziecko uzyskało wykształcenie wyższe magisterskie lub lekarskie, niemal jedna czwarta $(24,1 \%)$ - wyższe licencjackie, inżynierskie, a 11,1\% - przynajmniej stopień naukowy doktora (Kozłowski, Matczak 2012, s. 11), z kolei 40\% rodziców nie jest skłonnych do żadnych ustępstw w tym zakresie, niezależnie od okoliczności (tamże, s. 31). 
Uwarunkowanie III - nierealna wizja szkoły. Co rodzice wiedzą o szkole i postawach swoich dzieci? Z analiz wynika, że rodzice idealizują szkołę i swoje dzieci. Badania "Diagnoza szkolna 2009" Janusza Czapińskiego, zrealizowane w ramach programu społecznego "Szkoła bez przemocy", w części poświęcone zostały rodzicom i ich opiniom na temat przemocy oraz innych problemów polskiej szkoły. Wyniki wskazują duże rozbieżności między zdaniem osób dorosłych a opiniami ich dzieci. W odniesieniu do interesujących nas $w$ tej analizie treści warto przytoczyć kilka wyników badań:

$\rightarrow A z ̇ ~ 83 \%$ rodziców uważa, że ich dzieci spędzają większość czasu w domu - one jednak dwukrotnie częściej twierdzą, że jest odwrotnie. Około $28 \%$ i $24 \%{ }^{5}$ badanych uczniów szkół podstawowych twierdzi, że więcej czasu spędza poza domem, tego samego zdania jest jedynie $18 \%$ i $16 \%$ rodziców, na etapie gimnazjalnym odsetek ten wynosi: $33 \%$ i $28 \%$ oraz $15 \%$ i $11 \%$, na ponadgimnazjalnym odpowiednio: $43 \%$ i $28 \%$ oraz $15 \%$ i $17 \%$.

$\rightarrow$ Zdaniem rodziców, dzieci spędzają o połowę mniej czasu w internecie, niż same twierdzą (Czapiński 2009, s. 33).

$\rightarrow$ Badania pokazują, że wraz z wiekiem dziecka spada aktywność społeczna. Prawie co drugi uczeń ostatnich klas szkoły podstawowej (wówczas sześcioletniej) deklaruje, że udziela się w wolontariacie $(46 \%)$, a zdaniem rodziców - odsetek ten wynosi $62 \%$. Pod koniec szkoły średniej do działalności społecznej przyznaje się co piąty nastolatek (21\%), a według rodziców zajmuje się nią $41 \%$ ich dzieci (Czapiński 2010, s. 35).

$\rightarrow$ Rodzice rzadko lub bardzo rzadko zdają sobie sprawę z tego, że ich dziecko pada ofiarą szkolnej przemocy: $87 \%$ z nich uznało, że problem ten „w ogóle" lub "raczej” nie jest poważny. Tymczasem ok. $30 \%$ dzieci twierdzi, że jest to istotna kwestia w ich szkole. Połowa jedenastolatków mówi o przemocy psychicznej (30\% rodziców), $54 \%$ czternastolatków (jedynie $9 \%$ rodziców), $38 \%$ osiemnastolatków ( $10 \%$ rodziców). Podobnie jest z przemocą nauczyciela wobec ucznia: $21 \%$ jedenastolatków twierdzi, że w szkole dochodzi do takich zdarzeń, a podobnego zdania jest $9 \%$ rodziców, $38 \%$ osiemnastolatków wskazuje istnienie tego 
problemu - wobec $9 \%$ twierdzących tak rodziców (Czapiński 2010, s. 37-38);

$\rightarrow$ Rodzice są słabo zaangażowani w życie szkoły. Średnio jedna czwarta z nich nie utrzymuje żadnych kontaktów z placówką edukacyjną. Im starsze jest ich dziecko, tym związek ze szkołą jest słabszy. Brak kontaktów ze szkołą deklaruje 13\% rodziców uczniów szkół podstawowych, 25\% na poziomie gimnazjów i $30 \%$ szkół ponadgimnazjalnych. Nawet gdy pojawiają się kłopoty, co piąty rodzic nie komunikuje się ze szkołą, $76 \%$ rodziców deklaruje udział w każdej wywiadówce - dzieci oceniają, że w spotkaniach z nauczycielem uczestniczy jedynie $56 \%$ z nich (Czapiński 2010, s. 39-40). 